\title{
PENGARUH PERSPEKTIF WAKTU (TIME PERSPECTIVE) TERHADAP KUALITAS RELASI SOSIAL
}

\author{
Evanytha \\ Fakultas Psikologi \\ Universitas Pancasila \\ J1. Srengseng Sawah, Jagakarsa, Jakarta Selatan 12640, Indonesia \\ evaoktober@yahoo.com
}

\begin{abstract}
One important and basic aspect of human subjective experience is time. Existentialists stated that humans are beings who exist in relation to a specific time and place, and specific meaning. Time is an element of human existence, which underlies and regulate individual social behavior. The objective of this study was to examine the effect of time perspective on quality of social relation. Participants were 96 undergraduate students. This study used Zimbardo Time Perspective Inventory and Positive Relation with Others scales. The ZTPI contains five dimensions: Past-Positive, Past-Negative, PresentHedonistic, Present-Fatalistic and Future. Data analysis used multiple regression. The result showed there was effect of five dimensions of time perspective on quality of social relation. Dimensions of Past-Positive and Future partially had significant effect on quality of social relation.
\end{abstract}

Key words: time perspective, quality of social relation, Zimbardo Time Perspective Inventory

\begin{abstract}
Abstrak
Salah satu pengalaman subyektif terpenting bagi manusia adalah waktu. Para eksistensialis menyatakan bahwa manusia adalah makhluk (being) yang ada dalam hubungannya dengan waktu dan tempat tertentu, serta makna tertentu. Waktu merupakan elemen dari eksistensi manusia, yang mendasari dan mengatur perilaku sosial individu. Penelitian ini bertujuan untuk mengetahui pengaruh perspektif waktu (time perspective) terhadap kualitas relasi sosial. Partisipan penelitian ini adalah 96 mahasiswa. Penelitian ini menggunakan skala Zimbardo Time Perspective Inventory dan Positive Relations with Others. Perspektif waktu meliputi lima dimensi, yaitu Past-Positive, Past-Negative, Present-Hedonistic, Present-Fatalistic dan Future. Analisis data menggunakan multiple regression. Hasil penelitian menunjukkan bahwa kelima dimensi perspektif waktu secara bersama-sama berpengaruh terhadap kualitas relasi sosial. Secara parsial, dimensi PastPositive dan Future berpengaruh signifikan terhadap kualitas relasi sosial.
\end{abstract}

Kata kunci: perspektif waktu, kualitas relasi sosial, Zimbardo Time Perspective Inventory 


\section{PENDAHULUAN}

\section{Latar Belakang}

Manusia pada dasarnya adalah makhluk sosial, dan kehidupan dalam kelompok dianggap sebagai salah satu mekanisme evolusioner dengan mana manusia dapat mempertahankan kelangsungan hidup dan berkembang (Caporael, 1997 dalam Taylor, Dickerson, \& Klein, 2005). Kehidupan dalam kelompok sosial telah memungkinkan individu untuk menghindari efek negatif dari keterbatasan fisik manusia terhadap spesies lain yang lebih besar, memiliki "senjata" seperti gigi dan taring, dan tingkat mobilitas serta kecepatan yang lebih tinggi. Hal ini menunjukkan bahwa relasi sosial merupakan aspek penting dalam kehidupan manusia (Taylor,dkk,2005).

Individu dikatakan memiliki kualitas relasi sosial yang positif jika mereka memiliki hubungan yang hangat, memuaskan, dan penuh kepercayaan dengan orang lain; memiliki perhatian terhadap kesejahteraan orang lain; memiliki kemampuan empati, afeksi, dan keintiman yang kuat dengan orang lain; dan memiliki pemahaman tentang memberi dan menerima dalam hubungan antarmanusia. Individu dengan skor rendah dalam kualitas relasi sosial yang positif memiliki sedikit hubungan yang dekat dan sedikit rasa percaya terhadap orang lain; mengalami kesulitan untuk bersikap hangat, terbuka, dan memperhatikan orang lain; terisolasi (terasing) dan frustrasi dalam hubungan interpersonal; dan tidak bersedia membuat kompromi-kompromi untuk mempertahankan hubungan yang penting dengan orang lain (Ryff; 1989,1995). Penelitian di bidang psikologi telah menunjukkan manfaat kehidupan kelompok bagi manusia, yang antara lain meliputi manfaat kesehatan dari hubungan sosial dan dukungan sosial, terutama pada saat stres. Penelitian Seeman (1996 dalam Taylor, dkk, 2005) melaporkan bahwa individu yang memiliki tingkat kuantitas dan kualitas relasi sosial yang tinggi berada pada tingkat risiko kematian yang rendah.

Uraian di atas menjelaskan bahwa manusia merupakan makhluk sosial dan memiliki kualitas relasi sosial yang baik merupakan hal yang penting bagi kehidupan yang optimal (Ryff \& Singer, 1998 dalam Taylor, dkk, 2005). Namun demikian, manusia tidak dapat didefinisikan hanya berdasarkan aspek sosial saja. Para filsuf dan psikolog eksistensial telah mendefinisikan manusia dalam berbagai aspek yang esensial bagi eksistensinya. Heidegger (1962) menyatakan bahwa eksistensi manusia ada dalam waktu. Rollo May (dalam Monte \& Sollod, 2003) menjelaskan bahwa manusia adalah makhluk (being) yang ada dalam hubungannya dengan waktu, tempat, serta makna tertentu.

Salah satu pengalaman subyektif terpenting bagi manusia adalah waktu. Waktu merupakan elemen dari eksistensi manusia, yang mendasari dan mengatur perilaku sosial individu (Boniwell \& Zimbardo, 2004). Waktu begitu banyak meresapi dan mendefinisikan eksistensi individu, sehingga waktu dapat berkaitan dengan berbagai konstruk psikologis (Zimbardo \& Boyd, 1999).

Zimbardo, Keough, dan Boyd, (1997) mendefinisikan perspektif waktu sebagai "cara individu dan budaya membagi arus (flow) pengalaman manusia menjadi kategori temporal masa lampau, masa sekarang, dan masa depan yang terpisah". Perspektif waktu dibagi atas lima dimensi atau faktor, yang meliputi Past-Positive, Past-Negative, Present-Hedonistic, Present-Fatalistic, dan Future (Zimbardo \& Boyd, 1999). Terdapat sejumlah penelitian mengenai perspektif waktu dalam kaitannya dengan variabel-variabel psikologis tertentu. Zimbardo,dkk (1997) melaporkan hasil penelitian mereka bahwa Present Time Perspective merupakan prediktor perilaku mengemudi berisiko, penggunaan akohol, merokok, dan konsumsi zat psikoaktif secara ilegal. Penelitian lain menemukan adanya hubungan antara perspektif waktu dengan variabel-variabel sikap, nilai, dan status, seperti prestasi akademik, kesehatan, pola tidur, dan pemilihan pasangan (Boniwell \& Zimbardo, 2004). 
Meskipun proses yang berkaitan dengan waktu merupakan hal yang penting dalam kehidupan manusia, namun ternyata psikologi hanya memberikan perhatian yang relatif sedikit dalam mengeksplorasi perspektif waktu secara sistematis (Boniwell \& Zimbardo, 2004). Telah ada sejumlah upaya untuk meneliti hubungan antara perspektif waktu dan variabel-variabel psikologis tertentu, namun penelitian-penelitian tersebut sering berfokus pada satu dimensi waktu, seperti hanya dimensi masa kini (Present) atau masa depan (Future). Penelitian-penelitian awal tentang ketiga orientasi waktu juga menunjukkan hasil yang tidak konsisten (Carr, 1985 dalam Boniwell \& Zimbardo, 2004). Belum banyak penelitian yang meneliti ketiga orientasi waktu tersebut secara bersamaan dan sebagian besar penelitian belum berhasil memberikan gambaran multidimensional dari perspektif waktu (Boniwell \& Zimbardo, 2004).

Penelitian-penelitian tentang perspektif waktu umumnya dilakukan dalam konteks budaya Barat. Penelitian tentang peran perspektif waktu pada budaya-budaya tertentu menunjukkan adanya pola tertentu. Cara hidup budaya Barat terutama merefleksikan orientasi berpikir ke masa depan, yang menjalankan nilai-nilai kapitalis (Boniwell \& Zimbardo, 2004). Budaya Timur memiliki fokus yang lebih besar ke masa lampau (Snyder \& Lopez, 2007), dan cenderung melihat self dan individu lain berada dalam hubungan harmonis yang saling tergantung satu sama lain (Kim, Triandis, Kagitcibasi, Choi, \& Yoon, 1994; Markus \& Kitayama, 1991 dalam Snyder \& Lopez, 2007).

Oleh karena itu, agar dapat memperoleh hasil penelitian yang komprehensif mengenai perspektif waktu dan adanya kemungkinan perbedaan budaya dalam konstruksi dan interpretasi perspektif waktu, maka penelitian ini ingin mengkaji pengaruh kelima dimensi perspektif waktu terhadap kualitas relasi sosial dalam konteks budaya Indonesia. Hal ini juga sejalan dengan pendapat Snyder dan Lopez (2007) yang menyatakan bahwa para pemikir psikologi positif di masa depan seharusnya tidak mengasumsikan bahwa teori-teori dan skala-skala yang didasarkan pada budaya Barat dapat diterjemahkan secara langsung pada budaya Timur. Lebih lanjut, Snyder dan Lopez (2007) juga menyatakan bahwa setiap teori dan pengukuran lintas budaya harus diuji sebelum membuat simpulan bahwa suatu penemuan dapat diterapkan secara universal.

\section{Kualitas Relasi Sosial}

Kualitas relasi sosial merupakan salah satu dari enam dimensi Psychological Well-Being yang dikemukakan oleh Ryff (1989, 1995), yaitu dimensi positive relation with others. Lima dimensi Psychological Well-Being lainnya meliputi self-acceptance, autonomy, environmental mastery, purpose in life, dan personal growth.

Relasi sosial merupakan hal yang penting bagi individu, baik secara mental maupun fisik. Isolasi sosial diasosiasikan dengan kesehatan yang lebih buruk. Individu yang memiliki lebih banyak tipe relasi sosial dan menghabiskan lebih banyak waktu dalam aktivitas sosial berada pada tingkat risiko lebih rendah terhadap penyakit dan kematian daripada individu yang terisolasi secara sosial (Berkman, Vaccarino, \& Seeman, 1993 $\rightarrow$ belum tercantum dalam Daftar Pustaka; Cohen, 1988; House, Landis, \& Umberson, 1988; dalam Pressman, Cohen, Miller, Barkin, Rabin, Treanor, 2005). Perasaan kesepian diasosiasikan dengan kesehatan fisik yang buruk, status imunitas yang buruk, merokok, konsumsi alkohol, kebiasaan olah raga yang buruk, kebiasaan tidur yang buruk, dan insomnia (Fees, Martin, \& Poon, 1999; Kiecolt-Glaser, Garner dkk., 1984; Berkman \& Syme, 1979; Cohen dkk., 1997; dalam Pressman dkk., 2005).

Menurut Yau dan Ho (1993), terdapat sejumlah prinsip yang mengarahkan tindakan sosial dalam budaya Timur, yaitu: (a) kepentingan kolektif atau kelompok lebih diutamakan daripada kepentingan individu, (b) pemenuhan kewajiban sosial eksternal lebih diutamakan daripada pemenuhan kebutuhan 
internal individu, dan (c) melindungi ketentraman sosial lebih diutamakan daripada ekspresi diri. Orientasi budaya Asia cenderung memusatkan perhatian pada pemenuhan kewajiban, sedangkan orientasi budaya Barat cenderung menganggap ekspresi diri dan pemenuhan kebutuhan individual sebagai hak yang harus dipertahankan terhadap pelanggaran oleh orang lain atau otoritas kolektif (Yau \& Ho, 1993).

\section{Perspektif Waktu (Time Perspective)}

Perspektif waktu meliputi lima dimensi atau faktor, yaitu Past-Positive, Past-Negative, PresentHedonistic, dan Present-Fatalistic (Zimbardo dan Boyd, 1999).

Past-Positive. Dimensi Past-Positive dicirikan oleh konstruksi positif, bersemangat, dan kerinduan terhadap masa lampau. Individu dengan perspektif waktu Past-Positive memiliki pandangan yang sehat terhadap kehidupan, tingkat kebahagiaan dan harga diri yang tinggi (Zimbardo \& Boyd, 1999).

Past Negative. Orientasi Past-Negative ditandai oleh pandangan yang negatif dan tidak menyukai masa lampau. Skor dimensi Past-Negative berkorelasi signifikan dengan depresi, kecemasan, ketidakbahagiaan, rasa rendah diri, dan agresi (Zimbardo \& Boyd, 1999).

Present-Hedonistic. Individu dengan orientasi Present-Hedonistic dicirikan oleh orientasi terhadap kesenangan dan kenikmatan saat ini, tanpa mengorbankan hari ini untuk imbalan di masa depan (Zimbardo \& Boyd, 1999). Mereka mencari sensasi baru dan menggairahkan, terbuka terhadap persahabatan dan petualangan seksual, dan bertindak dengan sedikit pertimbangan terhadap konsekuensi tindakan mereka, yang membuat mereka berisiko terhadap kecanduan, kecelakaan, serta kegagalan akademik dan karir (Boniwell \& Zimbardo, 2004).

Present-Fatalistic. Orientasi Present-Fatalistic mengungkapkan keyakinan bahwa masa depan telah ditakdirkan dan tidak dipengaruhi oleh tindakan-tindakan individu, sedangkan masa kini harus dijalani dengan kepasrahan (penerimaan) karena manusia ada di dalam kekuasaan takdir (Zimbardo \& Boyd, 1999), serta diasosiasikan dengan keputusasaan dan keyakinan bahwa kekuatan-kekuatan dari luar mengontrol kehidupan individu (Boniwell \& Zimbardo, 2004). Present-Fatalistic berkorelasi signifikan dengan agresi, kecemasan, dan depresi (Zimbardo \& Boyd, 1999).

Future. Dimensi Future dicirikan oleh perencanaan dan pencapaian tujuan masa depan (Zimbardo \& Boyd, 1999). Mereka memperhatikan konsekuensi dari keputusan dan tindakan saat ini, bekerja bagi tujuan dan imbalan di masa depan, seringkali dengan mengorbankan kesenangan saat ini, menunda kepuasan, dan menghindari godaan untuk membuang-buang waktu (Boniwell \& Zimbardo, 2004).

Budaya Barat memiliki pandangan yang cenderung linier mengenai waktu dan menekankan orientasi ke masa depan. Misalnya dengan membuat rencana dan menempatkan nilai bagi waktu, seperti "waktu adalah uang" (Snyder \& Lopez, 2007). Budaya Timur menghargai kekuatan dari "menoleh ke belakang" dan memahami kebijaksanaan orang-orang yang lebih tua. Selain itu, budaya Timur cenderung melihat self dan individu lain berada dalam hubungan harmonis yang saling tergantung satu sama lain (Kim, Triandis, Kagitcibasi, Choi, \& Yoon, 1994; Markus \& Kitayama, 1991 dalam Snyder \& Lopez, 2007). Penekanan terhadap manusia tersebut tampaknya membuat budaya Timur cenderung kurang memberikan perhatian terhadap aspek waktu dibandingkan budaya Barat (Snyder \& Lopez, 2007).

Tujuan Penelitian. Penelitian ini bertujuan untuk mengetahui pengaruh perspektif waktu (PastPositive, Past-Negative, Present-Fatalistic, Present-Hedonistic, dan Future) terhadap kualitas relasi sosial. 
Hipotesis. Hipotesis yang diajukan dalam penelitian ini adalah ada pengaruh perspektif waktu (Past-Positive, Past-Negative, Present-Fatalistic, Present-Hedonistic, dan Future) terhadap kualitas relasi sosial.

\section{METODE}

Partisipan. Partisipan penelitian ini adalah 96 mahasiswa (32 pria, 64 wanita). Usia partisipan berada pada rentang 18 sampai 41 tahun $(M=20.20, S D=2.82)$.

Desain. Penelitian ini merupakan penelitian noneksperimen karena tidak dilakukan kontrol langsung atau tidak dilakukan manipulasi terhadap variabel bebas dan randomisasi. Variabel yang diteliti adalah kualitas relasi sosial dan perspektif waktu (time perspective).

Prosedur. Teknik pengambilan sampel dalam penelitian ini adalah nonprobability sampling. Partisipan penelitian ditentukan secara aksidental, yaitu individu yang dijumpai oleh peneliti pada saat pengambilan data, memenuhi kriteria penelitian dan bersedia berpartisipasi sebagai partisipan.

Alat ukur. Alat ukur yang digunakan dalam penelitian ini Zimbardo Time Perspective Inventory (ZTPI) dan skala Positive Relation with Others. Zimbardo Time Perspective Inventory (ZTPI) digunakan untuk mengukur perspektif waktu. Terdapat lima faktor atau dimensi dalam perspektif waktu, yaitu: Past-Positive, Past-Negative, Present-Hedonistic, Present-Fatalistic, dan Future (Zimbardo \& Boyd, 1999). Pada versi asli dari ZTPI terdapat 56 item, namun yang digunakan dalam analisis data penelitian ini sebanyak 41 item. 15 item tidak digunakan dalam analisis data karena korelasi item-total yang rendah. ZTPI berbentuk skala Likert yang terdiri dari enam pilihan jawaban, dengan rentang dari Sangat Tidak Benar sampai Sangat Benar. Koefisien alpha Cronbach berkisar dari 0.664-0.798. Contoh item skala ZTPI: "Berpikir tentang masa lalu membuat saya merasa senang" (Past Positive).

Pengukuran kualitas relasi sosial pada penelitian ini menggunakan skala positive relation with others yang merupakan subskala dari dimensi dari Psychological Well-Being Scale (Ryff, 1989, 1995; Abbott, Ploubidis, Huppert, Kuh, \& Croudace, 2010). Skala PWB terdiri dari enam subskala, yaitu selfacceptance, autonomy, environmental mastery, purpose in life, personal growth, dan positive relation with others. Untuk pengukuran kualitas relasi sosial, maka digunakan hanya subskala yang relevan dengan tujuan penelitian ini, yaitu subskala positive relation with others. Skala positive relation with others terdiri dari 7 item dalam bentuk skala Likert dengan enam pilihat jawaban, yang berkisar dari "Sangat Tidak Setuju" sampai "Sangat Setuju". Koefisien alpha Cronbach untuk skala positive relation with others adalah $0.720(M=30.26, S D=4.85)$. Contoh item: "Saya sering merasa kesepian karena saya hanya punya sedikit teman dekat dengan siapa saya berbagi kekuatiran".

Teknik Analisis. Penelitian ini menggunakan teknik multiple regression untuk mengetahui pengaruh perspektif waktu terhadap kualitas relasi sosial. Uji reliabilitas instrumen penelitian menggunakan alpha Cronbach. Analisis data menggunakan SPSS 13.0 for Windows.

\section{ANALISIS \& HASIL}

Hasil penelitian menunjukkan bahwa terdapat pengaruh yang signifikan dari perspektif waktu Past-Positive, Past-Negative, Present-Fatalistic, Present-Hedonistic, dan Future secara bersama-sama terhadap kualitas relasi sosial $(\mathrm{F}=4.792$, sig $(\mathrm{p})=0.001, p<0.01)$. Sumbangan perspektif waktu Past-Positive, Past-Negative, Present-Fatalistic, Present-Hedonistic, dan Future terhadap kualitas 
relasi sosial adalah sebesar $21 \%(\mathrm{R}$ square $=0.210)$, sedangkan sisanya sebesar $79 \%$ dipengaruhi faktor lain.

Secara parsial, perspektif waktu Past-Positive $(t=3.273, p<0.01)$ dan Future $(t=2.670, p$ $<0.01)$ merupakan prediktor yang signifikan terhadap kualitas relasi sosial. Perspektif waktu PastPositive $($ Beta $=0.324)$ lebih berpengaruh terhadap kualitas relasi sosial dibandingkan dengan Future $($ Beta $=0.261)$. Data hasil penelitian dapat dilihat pada Tabel 1 .

Tabel 1. Pengaruh Perspektif Waktu terhadap Kualitas Relasi Sosial

\begin{tabular}{|l|c|c|c|}
\hline Dimensi Time Perspective & $\mathbf{t}$ & Sig (p) & Beta \\
\hline Past-Positive & 3.273 & 0.002 & 0.324 \\
\hline Past-Negative & -1.329 & 0.187 & -0.150 \\
\hline Present-Hedonistic & -1.278 & 0.205 & -0.142 \\
\hline Present-Fatalistic & 0.759 & 0.450 & 0.084 \\
\hline Future & 2.670 & 0.009 & 0.261 \\
\hline
\end{tabular}

\section{DISKUSI}

Hasil penelitian ini menunjukkan bahwa perspektif waktu Future dan Past-Positive berpengaruh terhadap kualitas relasi sosial. Dengan demikian, hasil penelitian ini mendukung penelitian yang dilakukan oleh Zimbardo dan Boyd (1999), bahwa individu yang berorientasi Past-Positive memiliki pandangan yang sehat terhadap kehidupan, dan dimensi Past-Positive berkorelasi positif dengan tingkat kebahagiaan, harga diri (self-esteem), dan keramahan (friendliness). Pandangan yang sehat terhadap kehidupan, harga diri yang positif serta keramahan tersebut membuat individu dengan perspektif waktu Past-Positive mampu bersikap hangat, mampu mempercayai orang lain, mampu berempati dan memiliki perhatian terhadap kesejahteraan orang lain, yang membuat mereka mampu menjalin relasi sosial yang positif dengan orang lain.

Dari hasil penelitian ini diketahui bahwa perspektif waktu Future berpengaruh terhadap kualitas relasi sosial. Boniwell dan Zimbardo (2004) menyatakan bahwa individu dengan perspektif waktu masa depan (Future) dicirikan oleh perencanaan dan pencapaian tujuan masa depan, serta memperhatikan konsekuensi dari tindakan saat ini. Mereka bekerja bagi tujuan di masa depan, seringkali dengan mengorbankan kesenangan saat ini dan menghindari godaan untuk membuang-buang waktu. Individu dengan orientasi Future secara umum lebih sukses dalam pendidikan dan karir daripada individu dengan perspektif waktu lainnya. Namun orientasi terhadap masa depan yang berlebihan cenderung untuk mengurangi kebutuhan individu akan hubungan sosial, dan rasa keterlibatan dalam komunitas dan tradisi kultural (Boniwell \& Zimbardo, 2004). Partisipan penelitian ini adalah mahasiswa yang sebagian besar berasal dari kelas menengah dan hidup di Jakarta, sehingga mereka memiliki pola berpikir yang berorientasi kepada masa depan, yaitu keberhasilan pencapaian tujuan-tujuan. Misalnya, lulus kuliah dengan hasil yang baik dan mendapat pekerjaan. Selain itu, status sebagai mahasiswa juga membuat mereka dapat memperoleh akses yang lebih mudah kepada informasi, misalnya internet, buku, dan film, sehingga mereka tidak asing dengan nilai-nilai budaya Barat, yang salah satunya menekankan orientasi ke masa depan. 


\section{SIMPULAN \& SARAN}

Manusia merupakan mahkluk sosial, sehingga memiliki kualitas relasi sosial yang positif dengan orang lain merupakan hal yang penting bagi kehidupan yang optimal. Hasil penelitian menunjukkan bahwa kelima perspektif waktu (Past-Positive, Past-Negative, Present-Hedonistic, Present-Fatalistic, dan Future) secara bersama-sama berpengaruh terhadap kualitas relasi sosial. Secara parsial, terdapat dua dimensi perspektif waktu yang berpengaruh terhadap kualitas relasi sosial, yaitu Past-Positive dan Future.

Keterbatasan penelitian ini adalah dalam hal karakteristik partisipan yang relatif homogen dari segi pendidikan, usia, dan tingkat sosial ekonomi. Penelitian selanjutnya yang melibatkan partisipan dengan latar belakang sosial dan etnis yang lebih bervariasi akan memperkaya hasil penelitian.

\section{DAFTAR PUSTAKA}

Abbott, R. A., Ploubidis, G. B., Huppert, F. A., Kuh, D., \& Croudace, T. J. (2010). An evaluation of the precision of measurement of Ryff's psychological well-being scales in a population sample. Social Indicators Research, 97, 357-373.

Boniwell, I., \& Zimbardo, P. G. (2004). Balancing time perspective in pursuit of optimal functioning. Dalam P. A. Linley, \& S. Joseph. (Eds). Positive psychology in practice. New Jersey: John Wiley \& Sons.

Heidegger, M. (1962). Being and time. Oxford: Basil Blackwell Publisher, Inc.

Monte, C. F., \& Sollod, R. F. (2003). Beneath the mask. An introduction to theories of personality (7th ed.). New York: John Wiley \& Sons, Inc.

Pressman, S. D., Cohen, S., Miller, G. E., Barkin, A., Rabin, B. S., Treanor, T. T. (2005). Loneliness, Social Network Size, and Immune Response to Influenza Vaccination in College Freshmen. Health Psychology, 24, 297-306.

Ryff, C. D. (1989). Happiness is everything, or is it? Explorations on the meaning of psychologicalwell being. Journal of Personality and Social Psychology, 57, 1069-1081.

Ryff, C. D. (1995). The structure of psychological well-being revisited. Journal of Personality and Social Psychology, 69, 719-727.

Snyder, C. R., \& Lopez, S. L.(2007). Positive psychology. The scientific and practical explorations of human strength. California: Sage Publication, Inc.

Taylor, S. E., Dickerson, S. S., \& Klein, L. C. (2005). Toward a biology of social support. Dalam C. R. Snyder, \& S. J. Lopez (Ed.). Handbook of positive psychology. Oxford: Oxford University Press.

Yau, D., \& Ho, F. (1993). Relational orientation in Asian social psychology. Dalam U. Kim, \& J. W. Berry. Indigenous psychologies. Research and experience in cultural context. Vol. 17, Cross cultural research and methodology series. London: Sage Publications, 240-259.

Zimbardo, P. G., Keough, K. A., \& Boyd, J. N. (1997). Present time perspective as a predictor of risky driving. Personality and Individual Differences, 23, 1007-1023.

Zimbardo, P. G., \& Boyd, J. N. (1999). Putting time in perspective: A valid, reliable individualdifferences metric. Journal of Personality and Social Psychology, 77, 1271-1288. 
